Article

\title{
Impact of Land Use Intensity on Ecosystem Services: An Example from the Agro-Pastoral Ecotone of Central Inner Mongolia
}

\author{
Qian $\mathrm{Li}^{2,6}$, Xuefeng Zhang ${ }^{2,3}$, Qingfu Liu ${ }^{2,3}$, Yang Liu ${ }^{1,2,3}$, Yong Ding ${ }^{4,5, *}$ and \\ Qing Zhang 2,3,5,* \\ 1 State Key Laboratory of Earth Surface Processes and Resource Ecology, Beijing Normal University, \\ Beijing 100875, China; yang_liu@mail.bnu.edu.cn \\ 2 School of Ecology and Environment, Inner Mongolia University, Hohhot 010021, China; \\ liqian0921@mail.imu.edu.cn (Q.L.); xfzhang2003@mail.imu.edu.cn (X.Z.); qingfuliu@mail.imu.edu.cn (Q.L.) \\ 3 Inner Mongolia Key Laboratory of Grassland Ecology, Hohhot 010021, China \\ 4 Grassland Research Institute of the Chinese Academy of Agricultural Sciences, Hohhot 010010, China \\ 5 Key Laboratory of Grassland Ecology and Restoration of the Ministry of Agriculture, Hohhot 010010, China \\ 6 Institute of Subtropical Agriculture, Chinese Academy of Sciences, Changsha 410125, China \\ * $\quad$ Correspondence: dingyong@caas.cn (Y.D.); 111981346@imu.edu.cn (Q.Z.); Tel.: +86-471-492-6920 (Y.D.); \\ +86-471-499-2735 (Q.Z.)
}

Received: 6 April 2017; Accepted: 12 June 2017; Published: 15 June 2017

\begin{abstract}
Land use intensity is an important indicator of human activities, so we quantified the land use intensity and five ecosystem services (soil conservation, water conservation, carbon storage, net primary productivity (NPP), and crop production) in 13 subbasins of the Tabu River Basin in an agro-pastoral ecotone in central Inner Mongolia. Furthermore, we analyzed the relationships among ecosystem services and the responses of the services to the impact of land use intensity. The primary conclusions were as follows: (1) All five ecosystem services gradually diminished from the upper to the lower reaches of the Tabu River Basin; (2) Water conservation exhibited a trade-off relationship with soil conservation, NPP, and crop production, but it exhibited a synergistic relationship with carbon storage. There were also synergistic relationships between soil conservation, carbon storage, NPP, and crop production; (3) As land use intensity increased, soil conservation, NPP and crop production monotonically increased. In contrast, water conservation exhibited a monotonically decreasing trend, and carbon storage followed a unimodal curve; (4) In this region, suitable ecosystem services were sustained at a land use intensity of approximately 3.95.
\end{abstract}

Keywords: land use intensity; Inner Mongolia; agro-pastoral ecotone; regulating services; crop production

\section{Introduction}

Ecosystem services refer to the natural environmental conditions and utilities formed and maintained by ecosystems and ecological processes for human survival [1]. In accordance with the criteria set forth by the United Nations' Millennium Ecosystem Assessment, there are four categories of ecosystem services: provisioning, regulating, cultural, and supporting [2]. The Millennium Ecosystem Assessment reports that 15 of 24 ecosystem services (i.e., $~ 60 \%$ of all services assessed) are being degraded worldwide, and the destruction and degradation of ecosystem services pose a major threat to humanity by directly threatening human security and health and even influencing regional, as well as global, ecological security [2-4]. Human activities are believed to be primarily responsible for the deterioration of ecosystem services. Human activities can strongly influence ecosystem composition, structure, and function; this is particularly significant for the regulating and provisioning capacities of 
ecosystem services [5,6]. Therefore, an in-depth study highlighting the impact of human activities on ecosystem services has far-reaching implications.

Owing to the diversity and unbalanced spatial distribution of ecosystem services, as well as the specificity of human activities, the changes in one ecosystem service often lead to changes in other ecosystem services. The relationship between ecosystem services thus exhibits dynamic changes, primarily in the form of trade-offs and synergies [7,8]. A trade-off implies that some ecosystem services diminish with an increase in other ecosystem services; synergy signifies that two ecosystem services increase or decrease simultaneously [9]. There are two main mechanisms that maintain a trade-off or synergistic relationship between ecosystem services. For the first mechanism, when a factor drives multiple ecosystem services, the change in the driving factor causes feedback of the ecosystem services, resulting in a trade-off or synergistic relationship between the ecosystem services. With the second mechanism, the ecosystem services interact with each other, and the change of one ecosystem service has a direct impact on another ecosystem service [7,9]. Therefore, to obtain the maximum benefit from ecosystem services, the relationship between multiple ecosystem services must be considered to ensure balanced development [10,11]. For example, there is often a trade-off relationship between provisioning services (e.g., crop production and timber production) and regulating or supporting services (e.g., soil conservation, water purification, and biodiversity maintenance), whereas a synergistic relationship often exists between regulating or supporting services (e.g., air purification, vegetation carbon sequestration, and soil conservation) [12-14]. Thus, when investigating the impact of human activities on ecosystem services, multiple ecosystem services must be considered, rather than only pursuing the benefits of a particular ecosystem service $[15,16]$.

Land use/land cover is a direct indicator of the impact of human activities on terrestrial ecosystems, and it represents an interactive bond between natural ecological processes and human activities $[17,18]$. Human activities influence ecosystems in multiple aspects through direct and indirect impacts. Human activities can alter land use/land cover patterns and thus directly influence the capacity of various ecosystem services, and they can also simultaneously alter soil chemical properties, biogeochemical cycles, and biodiversity through various ecological processes, thereby indirectly influencing the quality of ecosystem services [19-21]. Land use intensity is a quantitative indicator of the intensity of the impact levied by human activities in terrestrial ecosystems, and it is often used to describe the intensity of human activities [21,22]. Different ecosystem services may exhibit a positive or negative correlation with land use intensity; a non-linear relationship may also exist $[19,23,24]$. Numerous studies have found that with increasing land use intensity, the provisioning services tend to increase, whereas the regulating or supporting services often decrease [22,25].

The agro-pastoral ecotone of China is a transitional zone between arid and semi-arid agricultural areas and pasture that originates along the southeastern margin of the Inner Mongolia Plateau. This ecotone extends through the western Liaoning, northern Hebei, northern Shanxi, and Shaanxi provinces and central Ningxia. It trends south-north at the boundary between Gansu and Qinghai and extends through western Sichuan and northwestern Yunnan, including the northern and southern sections. Given its unique geographical locations, the ecological environment of the agro-pastoral ecotone is extremely fragile, subjected to the dual impacts of climate and topography [26,27]. The land area of the agro-pastoral ecotone is 1.2968 million $\mathrm{km}^{2}$, i.e., $13.35 \%$ of the total area of China. There are 59.3031 million inhabitants within the agro-pastoral ecotone, i.e., $4.68 \%$ of the total population of China. The total grain yield of the agro-pastoral ecotone is 36.1187 million tons, i.e., $7.98 \%$ of the total grain yield of China. These figures demonstrate that the agro-pastoral ecotone holds a pivotal position in the national economy of China [26]. The agro-pastoral ecotone of Inner Mongolia constitutes an important component of China's agro-pastoral ecotone, and its position cannot be neglected. Existing research on ecosystem services in the agro-pastoral ecotone of Inner Mongolia has primarily focused on quantifying the ecosystem services and analyzing their patterns; however, there is limited research available concerning the impact of land use intensity on ecosystem services [28-30]. Thus, the present study was conducted in the Tabu River Basin in the agro-pastoral ecotone of central 
Inner Mongolia. The study quantifies land use intensity and five ecosystem services (soil conservation, water conservation, carbon storage, net primary productivity (NPP), and crop production) in this river basin. The primary purpose of the study was to evaluate the relationship between ecosystem services and the impact of land use intensity on ecosystem services. This study will enrich the theoretical research on ecosystem services. More importantly, we expect that our findings will provide scientific guidance regarding land use/land cover management in the agro-pastoral ecotone of Inner Mongolia and help achieve regional sustainable development.

\section{Study Area}

The Tabu River is a major river, flowing from south to north in the agro-pastoral ecotone of central Inner Mongolia. Based on a digital elevation model, digitized extraction was performed using the hydrology tools of ArcGIS 10.0 (ArcGIS, ERIS, Redlands, CA, USA). We delineated the boundary of the Tabu River Basin and further determined the scope of the study area, and we also identified 13 subbasins (Figure 1). The basin is located within the coordinates $41^{\circ} 2^{\prime}-42^{\circ} 32^{\prime} \mathrm{N}, 110^{\circ} 34^{\prime}-112^{\circ} 11^{\prime} \mathrm{E}$ and is characterized by a temperate continental climate. The annual average temperature ranges from -1.5 to $5.0^{\circ} \mathrm{C}$, and the average annual precipitation is $235 \mathrm{~mm}$. The altitude ranges between 1360 and $1700 \mathrm{~m}$. The topography comprises low hills in the south and high plains in the north. According to the World Reference Base for Soil Resources (WRB), the primary soil type in the study area is Chernozems.
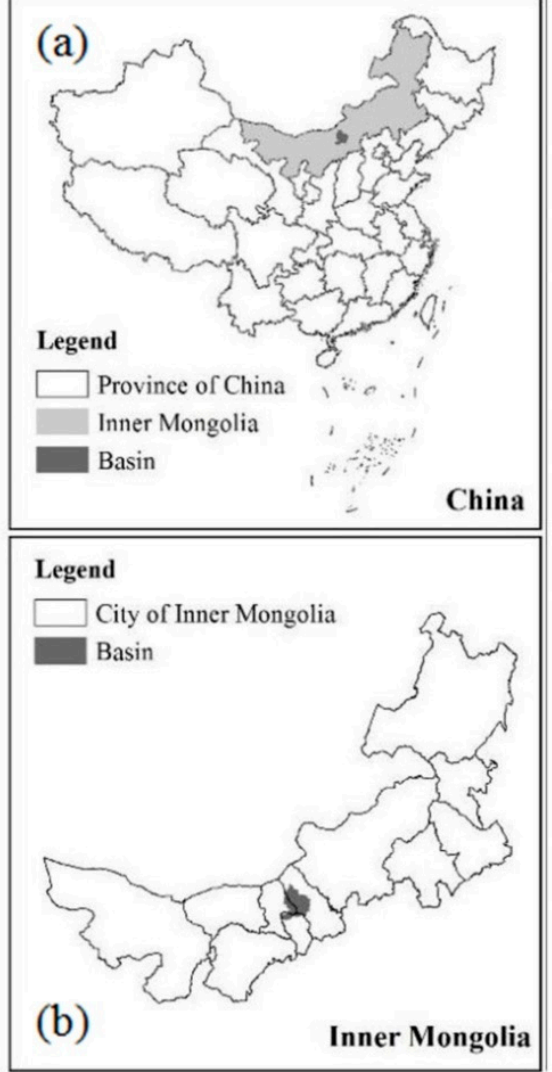

Figure 1. Map of the study area (a) The position of Inner Mongolia in China; (b) the position of study area in Inner Mongolia; (c) the distribution of 13 subbasins in study area.

\section{Methods}

The map of land use/land cover types used in this study was obtained through information extraction from remote sensing images (Landsat8, 2015; spatial resolution, $30 \mathrm{~m}$ ) of the study area and 1:250,000 road vector data for Inner Mongolia (National Basic Imagery Database of China). 
Land use/land cover types were classified using eCognition 8.6 software by combining single-band threshold, normalized difference vegetation index (NDVI) threshold, nearest neighbor classification, and vector classification methods, and seven land use/land cover types (cropland, forestry, bush, grassland, river, residential area, and road) were identified (Figure 2). An accuracy test was conducted using the Test and Training Area Mask (TTAMask) with field sample points as the basis. The overall accuracy was $88.40 \%$, and the Kappa coefficient was $85.58 \%$.
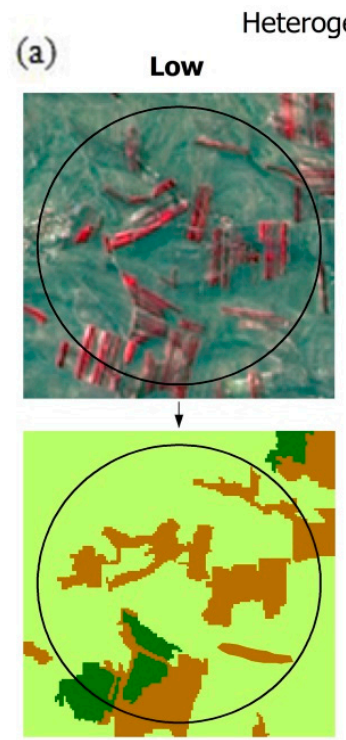

High
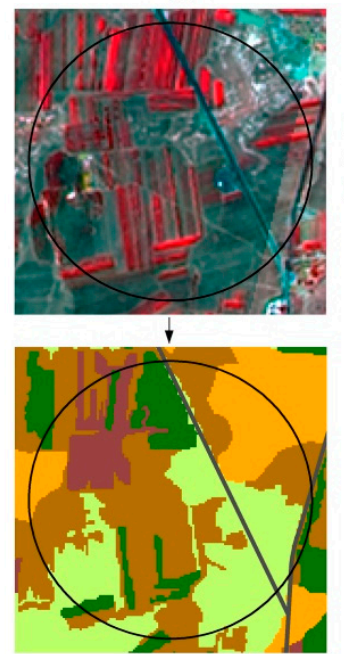

(b)

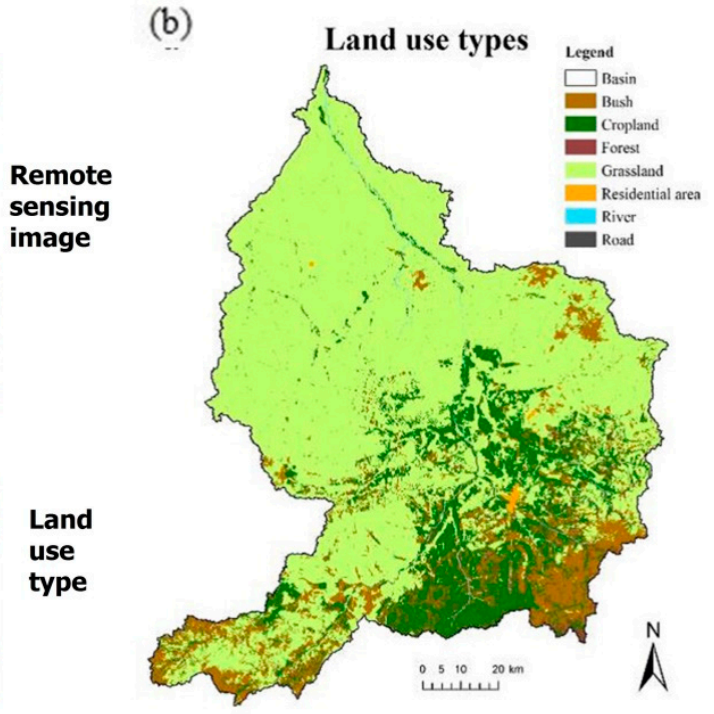

Figure 2. (a) Comparison of the original images and the extracted information; (b) spatial distribution of land use/land cover.

The formula used to calculate land use intensity in this study was proposed by Brown and Vivas [31] and was based on the different land use/land cover types in the study area and the of land use emergy per unit area, which has proven to be an effective indicator of the cumulative effect of human activities along a continuous gradient [32-34]. The land use intensity value of each town was calculated as the weighted value of each land use area using Equation (1):

$$
\mathrm{LUI}=\sum \% \mathrm{LU}_{\mathrm{i}} \times \mathrm{LDI}_{\mathrm{i}}
$$

where $\% \mathrm{LU}_{\mathrm{i}}$ is the proportion of the $i$-th land use in each town, and $\mathrm{LDI}_{\mathrm{i}}$ is the landscape development intensity (LDI) coefficient of the $i$-th land use type. The LDI coefficient quantifies human activities based on the emergy per unit area and per unit time. The emergy was transformed by natural logarithm and normalized into the range of 1.0-10.0 to obtain the LDI coefficient. In this formula, the emergy is a metric for quantifying human activity that measures the energy and materials (electricity, fuels, fertilizers, pesticides, and water) that are used directly and indirectly to make a product or provide a service [35], so different land use intensities correspond to different LDI coefficients. To accurately evaluate the land use intensity of the study area, we calibrated the LDI coefficient for every land use/land cover type based on the emergy weight coefficient proposed by Brown (Table 1). Completely natural land has an LDI coefficient of 1.0, and land characterized by a high intensity of interference has an LDI coefficient of 10.0 [31]. 
Table 1. LDI coefficients for each land use category.

\begin{tabular}{cccccccc}
\hline Land-Use Category & Cropland & Forestry & Bush & Grassland & River & Residential Area & Road \\
\hline LDI coefficient & 7.00 & 1.00 & 2.20 & 3.41 & 1.00 & 6.90 & 7.81 \\
\hline
\end{tabular}

In this study, we selected five ecosystem services: NPP, water conservation, soil conservation, carbon storage, and crop production. The CASA model was used to calculate NPP [36] based on the intercepted photosynthetically active radiation (IPAR) and light utilization efficiency $(\varepsilon)$ as

$$
\operatorname{NPP}(x, t)=\operatorname{IPAR}(x, t) \varepsilon(x, t)
$$

where $t$ is time, and $x$ is the grid cell.

Soil conservation was represented by soil erosion, which was estimated using the universal soil loss equation (USLE) [37]

$$
\mathrm{A}=\mathrm{R} \bullet \mathrm{K} \bullet \mathrm{L} \bullet \mathrm{S} \bullet \mathrm{C} \bullet \mathrm{P}
$$

where $\mathrm{A}$ is the computed soil per unit area; $\mathrm{R}$ is the rainfall factor; $\mathrm{K}$ is the soil-erodibility factor; $\mathrm{L}$ is the slope-length factor; $\mathrm{S}$ is the slope-gradient factor; $\mathrm{C}$ is the cropping-management factor; and $\mathrm{P}$ is the erosion-control practice factor. Therefore, a higher A indicates more severe soil erosion.

Both water conservation and carbon storage were estimated using the InVEST model. Water conservation was estimated using the water yield sub model of the InVEST model [38], in which the equation for water retention (WR) is

$$
\mathrm{WR}=\operatorname{Min}\left(1, \frac{249}{\text { Velocity }}\right) \cdot \operatorname{Min}(1,0.3 \mathrm{TI}) \cdot \operatorname{Min}\left(1, \frac{\mathrm{Ksat}}{300}\right) \cdot \mathrm{WY}
$$

where Velocity is the flow coefficient; TI is the topographic index; $K_{\text {sat }}$ is the soil saturated hydraulic conductivity; and WY is the water yield.

Carbon storage was estimated using the carbon storage sub model of the InVEST model. We calculated for $0-40 \mathrm{~cm}$ soil carbon, plant shoot carbon, and plant root carbon, the sum of which was considered the total carbon storage [39].

Crop production was derived from statistical data. We obtained the total planting area and total crop production for 2015 from the statistical yearbook and then calculated the crop production per unit area to determine the spatial distribution of crop production in the study area.

The Tabu River Basin contains a total of 13 subbasins, and the spatial patterns of land use/land cover and ecosystem services in each were analyzed using ArcGIS 10.0. Pearson correlation analysis was conducted to determine the relationship between ecosystem services and the impact of land use intensity on ecosystem services.

\section{Results}

\subsection{Spatial Pattern of Ecosystem Services}

Figure 3 shows that land use intensity, soil conservation, water conservation, carbon storage, NPP, and crop production were characterized by an overall declining trend from the southeast to the northwest. In other words, all five ecosystem services gradually decreased from the upper to the lower reaches of the Tabu River. 

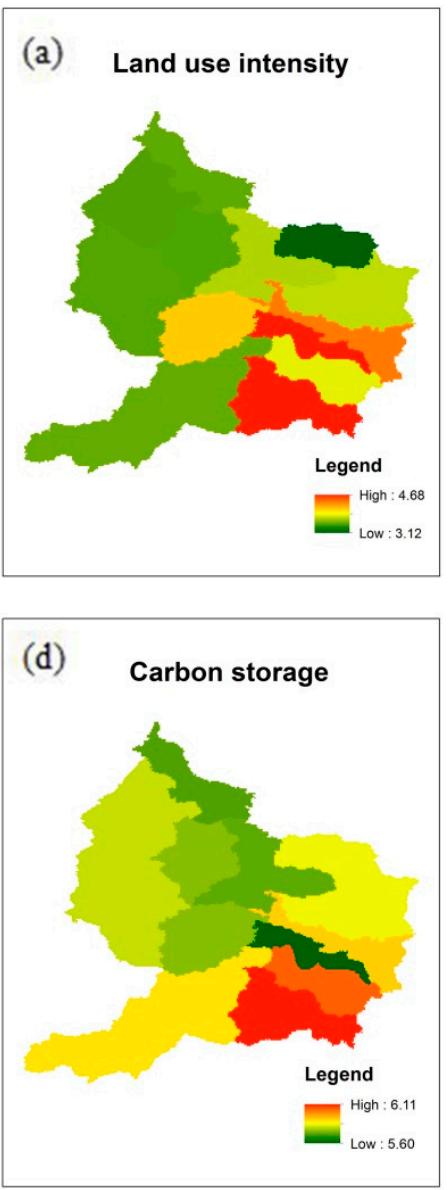
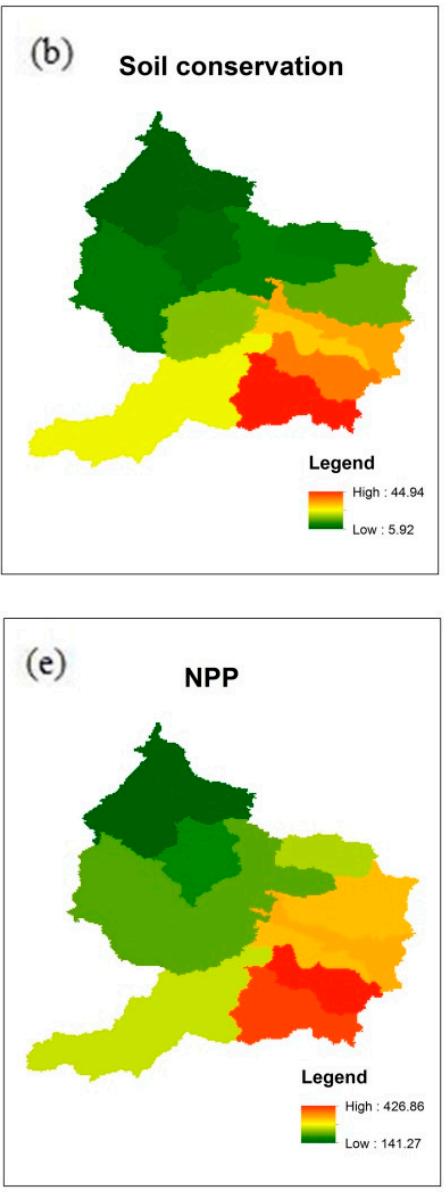
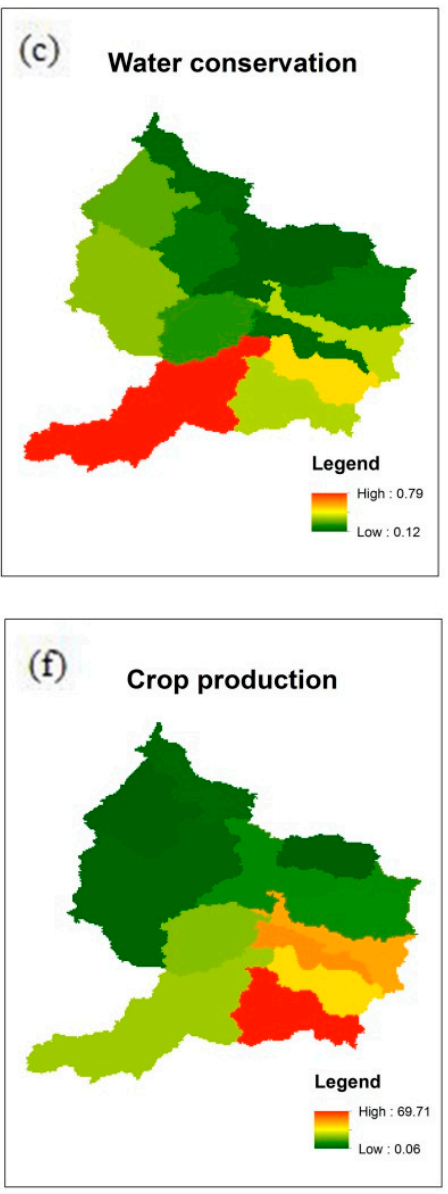

Figure 3. (a) Spatial distribution of land use intensity; (b) spatial distribution of soil conservation; (c) spatial distribution of water conservation; (d) spatial distribution of carbon storage; (e) spatial distribution of NPP; and (f) spatial distribution of crop production.

\subsection{Relationships between Ecosystem Services}

As shown in Table 2, water conservation exhibited a trade-off relationship with soil conservation, NPP, and crop production, but it exhibited a very weak synergistic relationship with carbon storage. Synergistic relationships were found between soil conservation, carbon storage, NPP, and crop production. The synergistic relationships were significant between soil conservation and NPP, between soil conservation and crop production, and between NPP and crop production.

Table 2. Relationships between ecosystem services

\begin{tabular}{cccccc}
\hline & Soil Conservation & Water Conservation & Carbon Storage & NPP & Crop Production \\
\hline Soil conservation & 1 & & & & \\
Water conservation & -0.416 & 1 & & & \\
Carbon storage & 0.529 & 0.010 & 1 & 1 & \\
NPP & $0.926^{* *}$ & -0.335 & $0.593^{*}$ & 1 & 1 \\
Crop production & $0.964^{* *}$ & -0.423 & 0.306 & $0.864^{* *}$ & \\
\hline
\end{tabular}

${ }^{*}$ represents significant correlation; ${ }^{* *}$ represents highly significant correlation.

\subsection{Impact of Land Use Intensity on Ecosystem Services}

Figure 4 shows the impact of land use intensity on the five ecosystem services. Significant increases occurred in NPP, soil conservation, and crop production with increasing land use intensity. Water conservation decreased with increasing land use intensity, but the trend was not significant $(P=0.887)$. 
Carbon storage represented by a non-significant unimodal curve with increasing land use intensity $(P=0.502)$. Carbon storage reached a maximum when land use intensity was approximately 3.95 .
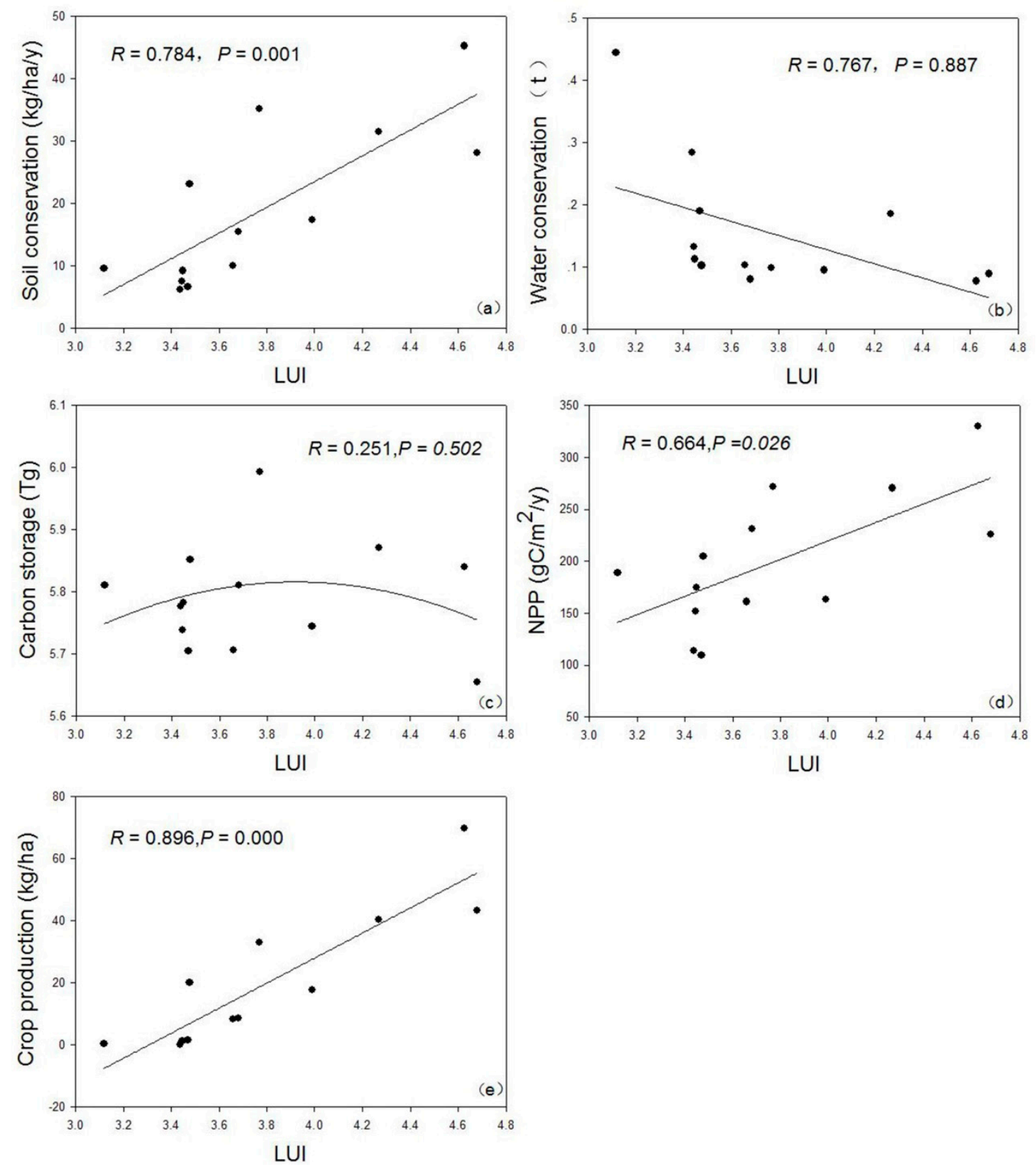

Figure 4. (a) Impact of land use intensity on soil conservation; (b) impact of land use intensity on water conservation; (c) impact of land use intensity on carbon storage; (d) impact of land use intensity on NPP; and (e) impact of land use intensity on crop production.

\section{Discussion and Conclusions}

\subsection{The Relationships between Ecosystem Services Primarily Include Trade-Offs and Synergies}

The relationships between ecosystem services are primarily trade-offs and synergies [21]. A series of studies have shown that synergistic relationships are often exhibited among regulating services, whereas provisioning and regulating services often have trade-off relationships $[10,25,40]$. In the present study, soil conservation, water conservation, carbon storage, and NPP were regulating services, and crop production was a provisioning service. Our study partially supports the conclusion of 
previous studies, as we found a trade-off relationship between crop production and water conservation and a synergistic relationship among three regulating functions (soil conservation, carbon storage, and NPP) (Table 2).

The results from our study differ from the findings of previous studies in that we found a synergistic relationship between the provisioning service (crop production) and three regulating services (NPP, soil conservation, and carbon storage), as well as a trade-off relationship between water conservation and two regulating services (soil conservation and NPP) (Table 2). This occurs because crop production and NPP are relatively high in regions with developed agriculture. Furthermore, soil structure is severely degraded in this region, likely resulting in greater soil erosion (which was reflection of soil conservation). Therefore, there is a synergistic relationship between crop production, NPP, and soil conservation. In a given ecosystem, more than $90 \%$ of carbon storage is derived from soil carbon. Compared with grasslands, croplands have more developed plant roots and relatively high carbon cycle rates, facilitating the accumulation of carbon in the soil [41]. Therefore, crop production and carbon storage share a synergistic relationship. Water conservation primarily depends on soil moisture content [42]. In regions with developed agriculture, the soil structure suffers more severe degradation, resulting in enhanced soil and water loss and a subsequent reduction in water conservation capacity. Therefore, water conservation was trade-off related to two regulating functions (soil conservation and NPP), but the correlations were not significant (Table 2). This may have been partly due to the limited sample number. Although the subbasin is an objective classification cell, there are only 13 subbasins in study area, so subsequent studies may require cells with a finer level of classification.

\subsection{The Impact of Human Activities on Ecosystem Services Is Not Simply Linear}

Numerous studies have found that as land use intensity increases, the provisioning services tend to increase, whereas the regulating services frequently decrease $[22,24,25]$. In our study, we also found that with increasing land use intensity, crop production increased, whereas soil conservation and water conservation decreased; this is consistent with previous studies.

The results from our study differ from those of the aforementioned previous studies in that, with an increase in land use intensity, the regulating service of NPP exhibited an increasing trend, whereas the regulating service of carbon storage exhibited a unimodal trend (Figure $4 a, c)$. Grazing and agricultural reclamation are the two most important human activities in the studied agro-pastoral ecotone. Given an increase in agricultural activities, land use intensity increases, and crop production and NPP increase correspondingly. Consequently, NPP increases as land use intensity increases. The ecological processes are highly complex and often non-linear. Thus, ecosystem services may not simply increase or decrease monotonically as a result of impacts from human activities; rather, a non-linear relationship may be exhibited [24]. In the present study, we found that the relationship between carbon storage and land use intensity conforms to a unimodal curve. That is, when land use intensity was less than 3.95, carbon storage increased with increasing land use intensity and reached a peak value at a land use intensity of approximately 3.95, but when land use intensity was greater than 3.95 , carbon storage decreased with increasing land use intensity. We considered the cropland area to increase with increasing land use intensity for values less than 3.95. Because of the special harvesting methods of the crop grown on the study area (keep the plant root and only reap the plant shoot), the carbon output is reduced. Therefore, croplands contain a higher carbon content than grasslands and thus increase total carbon storage. With an increase in land use intensity, cropland gradually transforms into construction land. The soil carbon storage of construction land is much lower than that of croplands and grasslands [43], thus resulting in a decreasing trend. For example, very high land use intensity but very low carbon storage were observed in the central area (green subbasin), as shown in Figure 3d, as this subbasin covers the urban area of Siziwang Banner. As mentioned above, our study is based on the subbasin scale, so there were only 13 samples. Therefore, we speculate that 
3.95 is not an absolute threshold value, so carbon storage may fluctuate approximately 3.95 with an increase in sample number.

\subsection{Recommendations for Regional Land Use}

Contributions from natural ecosystems to human society are irreplaceable. Natural ecosystems not only have direct value in terms of development and utilization but also immense indirect use value as well. However, the degradation of ecosystem services from human activities can be mitigated, and regional security can be improved through the rational management of land use/land cover $[3,4]$. Considering that there are often trade-off and synergistic relationships between ecosystem services, and that the impacts of land use intensity on ecosystem services are highly non-linear [6,44], it is unlikely that all services will be maximized simultaneously. Therefore, there is a need to develop reasonable land use/land cover patterns to achieve optimal ecosystem services and regional sustainable development. The relative importance of different ecosystem services depends primarily on those services for which humans have a greater need $[15,45,46]$.

The present study area is located in the agro-pastoral ecotone of central Inner Mongolia. Despite being very important economically, this region has a more important role as an ecological barrier in northern China and thus plays a key role in protecting the ecological environment of northern China, and its ecological environment directly determines the ecological environment of the northern China [26]. Regulating services have therefore received more attention among the various categories of ecosystem services. With an increase in land use intensity in this region, water conservation decreased; crop production, NPP, and soil and water loss increased; and carbon storage exhibited a unimodal curve. We speculate that a land use intensity value of 3.95 is more rational for this region; at approximately this intensity, carbon storage reached a maximum in the present study, whereas crop production, water conservation, and soil and water loss were moderate. We recommend a land use intensity value of 3.95 to maintain suitable ecosystem services in this region.

Acknowledgments: We thank Academic Editor and two anonymous reviewers for their insightful comments and helpful suggestions. We are very grateful to Jianguo Wu for his contribution to the idea of the study. This work was supported by the State Key Laboratory of Earth Surface Processes and Resource Ecology [Grant No. 2015-KF-11], the State Key Basic Research Development Program of China [Grant No. 2014CB138802] and the Basic Research program of Inner Mongolia [grant No. 2015MS0302].

Author Contributions: Qian Li, Xuefeng Zhang, Qingfu Liu, Yang Liu and Qing Zhang conducted the field experiment. Qian Li, Xuefeng Zhang, Qingfu Liu, Yang Liu, Yong Ding and Qing Zhang analyzed the data and contributed to drafting the paper. Yong Ding and Qing Zhang contributed to the concept and design of the paper. Yong Ding and Qing Zhang were in charge of the final version of the paper.

Conflicts of Interest: The authors declare no conflicts of interest.

\section{References}

1. Hooper, D.U.; Chapin, F.S.; Ewel, J.J.; Hector, A.; Inchausti, P.; Lavorel, S.; Lawton, J.H.; Lodge, D.M.; Loreau, M.; Naeem, S.; et al. Effects of biodiversity on ecosystem functioning: A consensus of current knowledge. Ecol. Monogr. 2005, 75, 3-35. [CrossRef]

2. Millennium Ecosystem Assessment. Ecosystems and Human Well-Being; Island Press: Washington, DC, USA, 2005.

3. Raudsepp-Hearne, C.; Peterson, G.D.; Bennett, E.M. Ecosystem service bundles for analyzing tradeoffs in diverse landscapes. Proc. Natl. Acad. Sci. USA 2010, 107, 5242-5247. [CrossRef] [PubMed]

4. Lavorel, S.; Grigulis, K.; Lamarque, P.; Colace, M.-P.; Garden, D.; Girel, J.; Pellet, G.; Douzet, R. Using plant functional traits to understand the landscape distribution of multiple ecosystem services. J. Ecol. 2011, 99, 135-147. [CrossRef]

5. Pergams, O.R.W.; Zaradic, P.A. Evidence for a fundamental and pervasive shift away from nature-based recreation. Proc. Natl. Acad. Sci. USA 2008, 105, 2295-2300. [CrossRef] [PubMed] 
6. Van Jaarsveld, A.S.; Biggs, R.; Scholes, R.J.; Bohensky, E.; Reyers, B.; Lynam, T.; Musvoto, C.; Fabricius, C. Measuring conditions and trends in ecosystem services at multiple scales: The southern African millennium ecosystem assessment (safma) experience. Philos. Trans. R. Soc. B Biol. Sci. 2005, 360, 425-441. [CrossRef] [PubMed]

7. Lester, S.E.; Costello, C.; Halpern, B.S.; Gaines, S.D.; White, C.; Barth, J.A. Evaluating tradeoffs among ecosystem services to inform marine spatial planning. Mar. Policy 2013, 38, 80-89. [CrossRef]

8. Ma, F.; Eneji, A.E.; Liu, J. Understanding relationships among agro-ecosystem services based on emergy analysis in Luancheng county, north China. Sustainability 2014, 6, 8700-8719. [CrossRef]

9. Rodriguez, J.P.; Beard, T.D., Jr.; Bennett, E.M.; Cumming, G.S.; Cork, S.J.; Agard, J.; Dobson, A.P.; Peterson, G.D. Trade-offs across space, time, and ecosystem services. Ecol. Soc. 2006, 11, 709-723. [CrossRef]

10. Bennett, E.M.; Peterson, G.D.; Gordon, L.J. Understanding relationships among multiple ecosystem services. Ecol. Lett. 2009, 12, 1394-1404. [CrossRef] [PubMed]

11. Mace, G.M.; Norris, K.; Fitter, A.H. Biodiversity and ecosystem services: A multilayered relationship. Trends Ecol. Evol. 2012, 27, 19-26. [CrossRef] [PubMed]

12. Grasso, M. Ecological-economic model for optimal mangrove trade off between forestry and fishery production: Comparing a dynamic optimization and a simulation model. Ecol. Model. 1998, 112, 131-150. [CrossRef]

13. Aillery, M.; Shoemaker, R.; Caswell, M. Agriculture and ecosystem restoration in south florida: Assessing trade-offs from water-retention development in the everglades agricultural area. Am. J. Agric. Econ. 2001, 83, 183-195. [CrossRef]

14. Egoh, B.; Reyers, B.; Rouget, M.; Bode, M.; Richardson, D.M. Spatial congruence between biodiversity and ecosystem services in south Africa. Biol. Conserv. 2009, 142, 553-562. [CrossRef]

15. Bennett, E.M.; Balvanera, P. The future of production systems in a globalized world. Front. Ecol. Environ. 2007, 5, 191-198. [CrossRef]

16. Carpenter, S.R.; Mooney, H.A.; Agard, J.; Capistrano, D.; DeFries, R.S.; Diaz, S.; Dietz, T.; Duraiappah, A.K.; Oteng-Yeboah, A.; Pereira, H.M.; et al. Science for managing ecosystem services: Beyond the millennium ecosystem assessment. Proc. Natl. Acad. Sci. USA 2009, 106, 1305-1312. [CrossRef] [PubMed]

17. Mooney, H.A.; Duraiappah, A.; Larigauderie, A. Evolution of natural and social science interactions in global change research programs. Proc. Natl. Acad. Sci. USA 2013, 110, 3665-3672. [CrossRef] [PubMed]

18. Haberl, H.; Wackernagel, M.; Wrbka, T. Land use and sustainability indicators. An introduction. Land Use Policy 2004, 21, 193-198. [CrossRef]

19. Allan, E.; Manning, P.; Alt, F.; Binkenstein, J.; Blaser, S.; Bluethgen, N.; Boehm, S.; Grassein, F.; Hoelzel, N.; Klaus, V.H.; et al. Land use intensification alters ecosystem multifunctionality via loss of biodiversity and changes to functional composition. Ecol. Lett. 2015, 18, 834-843. [CrossRef] [PubMed]

20. Rivieccio, R.; Sallustio, L.; Paolanti, M.; Vizzarri, M.; Marchetti, M. Where land use changes occur: Using soil features to understand the economic trends in agricultural lands. Sustainability 2017, 9, 78. [CrossRef]

21. Felipe-Lucia, M.R.; Comin, F.A.; Bennett, E.M. Interactions among ecosystem services across land uses in a floodplain agroecosystem. Ecol. Soc. 2014, 19, 360-375. [CrossRef]

22. Kindu, M.; Schneider, T.; Teketay, D.; Knoke, T. Changes of ecosystem service values in response to land use/land cover dynamics in munessa-shashemene landscape of the Ethiopian highlands. Sci. Total Environ. 2016, 547, 137-147. [CrossRef] [PubMed]

23. Liiri, M.; Häsä, M.; E Haimi, J.; Setälä, H. History of land-use intensity can modify the relationship between functional complexity of the soil fauna and soil ecosystem services-A microcosm study. Appl. Soil Ecol. 2012, 55, 53-61. [CrossRef]

24. Niemela, J.; Saarela, S.-R.; Soderman, T.; Kopperoinen, L.; Yli-Pelkonen, V.; Vare, S.; Kotze, D.J. Using the ecosystem services approach for better planning and conservation of urban green spaces: A finland case study. Biodivers. Conserv. 2010, 19, 3225-3243. [CrossRef]

25. Xu, Y.; Tang, H.; Wang, B.; Chen, J. Effects of land-use intensity on ecosystem services and human well-being: A case study in Huailai county, China. Environ. Earth Sci. 2016, 75, 1-11. [CrossRef]

26. Chang, X.-H.; Zhao, G.-C.; Yang, Y.-S.; Feng, M.; Ma, S.-K.; Wang, D.-M.; Bi, Y.-Q.; Yang, S.-R. Effects of tillage mode and nitrogen application rate on nitrogen use efficiency of wheat in a farming-pasture zone of north China. Yingyong Shengtai Xuebao 2013, 24, 995-1000. (In Chinese) [PubMed] 
27. Zhang, J.-P.; Chang, X.-L.; Li, J.-Y.; Cai, M.-Y. Regional difference of land use/cover change in farmingpasturing zone of naiman banner in Inner Mongolia. Yingyong Shengtai Xuebao 2008, 19, 613-620. (In Chinese) [PubMed]

28. Ren, Y.; Lu, Y.; Fu, B. Quantifying the impacts of grassland restoration on biodiversity and ecosystem services in China: A meta-analysis. Ecol. Eng. 2016, 95, 542-550. [CrossRef]

29. Wang, H.; Zhou, S.; Li, X.; Liu, H.; Chi, D.; Xu, K. The influence of climate change and human activities on ecosystem service value. Ecol. Eng. 2016, 87, 224-239. [CrossRef]

30. Zhang, X.; Niu, J.; Buyantuev, A.; Zhang, Q.; Dong, J.; Kang, S.; Zhang, J. Understanding grassland degradation and restoration from the perspective of ecosystem services: A case study of the Xilin river basin in Inner Mongolia, china. Sustainability 2016, 8, 594. [CrossRef]

31. Brown, M.T.; Vivas, M.B. Landscape development intensity index. Environ. Monit. Assess. 2005, 101, $289-309$. [CrossRef] [PubMed]

32. Cohen, M.J.; Carstenn, S.; Lane, C.R. Floristic quality indices for biotic assessment of depressional marsh condition in Florida. Ecol. Appl. 2004, 14, 784-794. [CrossRef]

33. Mack, J.J. Landscape as a predictor of wetland condition: An evaluation of the landscape development index (ldi) with a large reference wetland dataset from Ohio. Environ. Monit. Assess. 2006, 120, 221-241. [CrossRef] [PubMed]

34. Margriter, S.C.; Bruland, G.L.; Kudray, G.M.; Lepczyk, C.A. Using indicators of land-use development intensity to assess the condition of coastal wetlands in Hawaii. Landsc. Ecol. 2014, 29, 517-528. [CrossRef]

35. Odum, H.T. Environmental Accounting: Emergy and Environmental Decision Making; Wiley: Maitland, FL, USA, 1996.

36. Potter, C.S.; Randerson, J.T.; Field, C.B.; Matson, P.A.; Vitousek, P.M.; Mooney, H.A.; Klooster, S.A. Terrestrial ecosystem production: A process model based on global satellite and surface data. Glob. Biogeochem. Cycles 1993, 7, 811-841. [CrossRef]

37. Wischmeier, W.H.; Smith, D.D. Predicting Rainfall-Erosion Losses from Cropland East of the Rocky Mountains; U.S. Government Printing Office: Washington, DC, USA, 1965.

38. Kareiva, P.; Tallis, H.; Ricketts, T.H.; Daily, G.C.; Polasky, S. Natural Capital: Theory and Practice of Mapping Ecosystem Services; Oxford University Press: London, UK, 2011.

39. Leslie, H. M. Natural capital theory and practice of mapping ecosystem services. Science 2011, 332, $1264-1265$. [CrossRef]

40. Tao, Y.; Li, F.; Liu, X.; Zhao, D.; Sun, X.; Xu, L. Variation in ecosystem services across an urbanization gradient: A study of terrestrial carbon stocks from Changzhou, China. Ecol. Model. 2015, 318, 210-216. [CrossRef]

41. Chisholm, R.A. Trade-offs between ecosystem services: Water and carbon in a biodiversity hotspot. Ecol. Econ. 2010, 69, 1973-1987. [CrossRef]

42. Ponsioen, T.C.; Blonk, T.J. Calculating land use change in carbon footprints of agricultural products as an impact of current land use. J. Clean. Prod. 2012, 28, 120-126. [CrossRef]

43. Nelson, E.; Mendoza, G.; Regetz, J.; Polasky, S.; Tallis, H.; Cameron, D.R.; Chan, K.M.A.; Daily, G.C.; Goldstein, J.; Kareiva, P.M.; et al. Modeling multiple ecosystem services, biodiversity conservation, commodity production, and tradeoffs at landscape scales. Front. Ecol. Environ. 2009, 7, 4-11. [CrossRef]

44. Borjesson, P.; Tufvesson, L.M. Agricultural crop-based biofuels-Resource efficiency and environmental performance including direct land use changes. J. Clean. Prod. 2011, 19, 108-120. [CrossRef]

45. Farber, S.C.; Costanza, R.; Wilson, M.A. Economic and ecological concepts for valuing ecosystem services. Ecol. Econ. 2002, 41, 375-392. [CrossRef]

46. Sitas, N.; Prozesky, H.E.; Esler, K.J.; Reyers, B. Exploring the gap between ecosystem service research and management in development planning. Sustainability 2014, 6, 3802-3824. [CrossRef]

(C) 2017 by the authors. Licensee MDPI, Basel, Switzerland. This article is an open access article distributed under the terms and conditions of the Creative Commons Attribution (CC BY) license (http:/ / creativecommons.org/licenses/by/4.0/). 